\title{
Climate Change Impact on Yield, Quality and Soil Fertility of Maize in Sandy Clay Loam as Influenced By Biochar and Inorganic Nutrients in Typic Haplustalf
}

\author{
B. Gokila* \\ Long Term Fertilizer Experiment, Department of Soil Science and Agricultural Chemistry, \\ Tamil Nadu Agricultural University, Coimbatore - 641 003, Tamil Nadu, India \\ *Corresponding author
}

\section{A B S T R A C T}

To increase the accumulation of atmospheric carbon dioxide is due to the anthropogenic activity, natural fire and industrialization induced climate change. To increase the pressure regarding reduce the concentration of $\mathrm{CO}_{2}$ in the environment, sequestration of carbon is the trend to improve the carbon sink and environmental health in soil. The maintenance of

\section{Keywords}

Engineered char, Pyrolysis, Biochar, Carbon sequestration, Soil fertility, Climate change.

Article Info

Accepted:

24 September 2017 Available Online:

10 November 2017 a threshold level of organic matter in the soil is crucial for maintaining physical, chemical and biological integrity of the soil and also for the soil to perform its agricultural production and environmental functions. The application of biochar to the soil is proposed as a novel approach to establish a significant long term sink for atmospheric carbon dioxide in terrestrial ecosystems. For rising interest regarding carbon sequestration and soil sustainability field experiment was conducted to determine the influence of biochar and fertiliser with biofertiliser for yield, quality and soil fertility of maize in Typic Haplustalf of Tamirabharani tracts. The experiment was imposed with randomized block design with fifteen treatments (two levels of biochar and two levels of recommended dose of fertiliser with biofertiliser (Azophos 4 pockets ha $^{-1}$ ) and two replications. Application of biochar with inorganic fertilisers and biofertiliser increased the yield components of maize viz., hundred grain weight $(38.9 \mathrm{~g})$, cob length $(23.5 \mathrm{~cm})$, cob weight $(310 \mathrm{~g})$, grain yield $(8100$ $\left.\mathrm{kg} \mathrm{ha}^{-1}\right)$ and stover yield $\left(12,150 \mathrm{~kg} \mathrm{ha}^{-1}\right)$ and also quality trait such as crude protein content. Higher yield and quality was obtained from the combination of $5 \mathrm{t} \mathrm{ha}^{-1}$ plus 100 per cent recommended dose of $\mathrm{N}, \mathrm{P}_{2} \mathrm{O}_{5}$ and $\mathrm{K}_{2} \mathrm{O}$ plus biofertiliser on maize. The combined application of biochar with 100 per cent recommended dose of fertiliser and biofertiliser increased the yield, quality and soil fertility in maize growing soil.

\section{Introduction}

Greenhouse gases (e.g., $\mathrm{CO}_{2}, \mathrm{CH}_{4}$ ) from anthropogenic and biogenic sources are accumulating in the atmosphere. The concentration of atmospheric $\mathrm{CO}_{2}$ alone is projected to double from pre- industrial levels by the mid to late $21^{\text {st }}$ century. According to general circulation models of climate change, infrared radiation trapped by the additional greenhouse gases in the troposphere could cause the earth's surface temperature to increase 1.5 to $4.5^{\circ} \mathrm{C}$ and influence frequency and distribution of regional precipitation. To evaluate a possible means for offsetting part of the increase of atmospheric $\mathrm{CO}_{2}$, an assessment began in late 1990 to evaluate the potential to enhance $\mathrm{C}$ sequestration in global 
terrestrial ecosystems through forest and agroforest management. Climate change and fossil fuel shortage is a main concern for using renewable feedstock for energy. For replacing fossil fuel, agricultural wastes, crop residues and woods are subjected to conversion of energy through biological or thermal conversion. Pyrolysis of this biomass which is produces the char, oil and gases. Biochar and char which is produced through pyrolysis technique (thermal conversion). Agricultural waste and wood have the cellulose, hemicelluloses and lignin us a building unit. Through the thermal conversion process, these building units are produced the volatile products. Biochar is a product of thermal decomposition of biomass produced by a process termed pyrolysis. In recent years, application of black, charred carbon (biochar) has been increasingly discussed as a mitigation strategy for sequestering recalcitrant carbon into agricultural soils, which can, at the same time, improve soil fertility (Glaser et al., 2002). Modern pyrolysis techniques, which are currently undergoing a rapid technical development (Laird et al., 2010) allow energy production from syngas (mainly $\mathrm{CO}, \mathrm{H}_{2}$ and $\mathrm{CH}_{4}$ and other hydrocarbons) and / or liquid - fuel production while simultaneously generating different types of biochar. The resulting biochars can greatly differ in their material properties (CHO-concentrations, aromaticity, cation exchange capacity, $\mathrm{pH}$, nutrient contents, porosity, energy density etc.), depending on feedstock and pyrolysis conditions (Amonette and Joseph, 2009; Downie et al., 2009). Experimental evidence so far shows that biochar is quite stable and hence principally suitable for $\mathrm{C}$ sequestration (Major et al., 2010) and addition often promotes plant growth, in particular combined with $\mathrm{N}$-fertilizer addition in poor soils (Blackwell et al., 2009), and followed by it reduces nutrient leaching (Chan et al., 2008). Additionally it could be shown that the cation exchange capacity (CEC) of soils increases with biochar addition (Liang et al., 2006) in particular over time as the functional groups are oxidized (Cheng et al., 2008). Significant improvement in the available N, $\mathrm{P}, \mathrm{K}$ and DTPA- extractable $\mathrm{Zn}, \mathrm{Fe}, \mathrm{Cu}$ and Mn status at different growth stages of maize was evidenced with the conjoint application of biochar with fertilisers and biofertilisers. The present study was undertaken to study the effect of yield, quality and soil fertility in sandy clay loam as influenced by biochar in Typic Haplustalf.

\section{Materials and Methods}

\section{Preparation of Prosopis biochar}

Prosopis biochar is made by heating biomass under oxygen-limited conditions $\sim 450^{\circ} \mathrm{C}$ (e.g. slow pyrolysis).The thermo-chemical conversion drives off the volatile components of the biomass and stabilizes the remaining carbon into a black, highly aromatic solid.

\section{Characterization of Prosopis juliflora L. biochar}

The Biochar samples were collected from the pyrolysis stove sieved $(<0.25 \mathrm{~mm})$ and their important characteristics were analyzed (Table 2). The biochar sample was subjected to structural analysis for xylem structure and surface properties by using Scanning Electron Microscope at Tamil Nadu Agricultural University - Nano technology laboratory (Fig. 1). The degree of ashing, mobile or labile matter and resident matter or recalcitrant matter was analyzed and followed by characterizing biochar (Hugh McLaughlin. 2010).

\section{Biochar application}

Biochar was applied in different levels viz. 5.0 and $7.5 \mathrm{t} \mathrm{ha}^{-1}$ as soil application with two 
levels of NPK fertilization for maize. The biochar was applied uniformly in the respective plots at $5 \mathrm{~cm}$ depth of the soil prior to sowing.

\section{Study site description}

A field experiment was conducted in farmer's field at Sivasubramaniyapuram village near to the Agricultural College and Research Institute, Killikulam of Thoothukudi district with test crop of maize during 2011-2012 to evaluate the impact of soil applied Prosopis biochar on yield and quality of maize in Alfisol.

The experimental site located at $80^{\circ} 46^{\prime} \mathrm{N}$ latitude and $77^{\circ} 42^{\prime}$ longitude at an elevation of 40 meters above mean sea level. The soil of the experimental site belonged to Sivasubramaniapuram series and according to USDA soil taxonomy it could be classified as Sandy clay loam, fine non arid Kaolinticisomegathermic family of TypicHaplustalfs. The characteristics of the experiment soil, determined by standard methods are presented in Table 1. Crude protein was analyzed by using this formula $\mathrm{N}$ (\%) content $\times$ conversion factor 6.25 . The method as suggested by Merrill and Watt (1973).

\section{Experimental description}

A field experiment for yield, quality and soil fertility of maize hybrid (Pioneer 30R77) was investigated with different levels of biochar, fertilizers and biofertilisers during September 2011 - January 2012. The experimental soil was sandy clay loam in texture with the $\mathrm{pH}$, EC, CEC and organic carbon content of 6.2, $0.45 \mathrm{ds} \mathrm{m}^{-1}, 16 \mathrm{c} \mathrm{mol}(\mathrm{p}+) \mathrm{kg}^{-1}$ and 0.43 per cent respectively. The soil was low in $\mathrm{KMnO} 4$ - N (223.4 kg ha $\left.{ }^{-1}\right)$, medium in Olsen - P $\left(11.32 \mathrm{~kg} \mathrm{ha}^{-1}\right)$ and low in $\mathrm{NH}_{4} \mathrm{OAc}-\mathrm{K}$ $\left(270.7 \mathrm{~kg} \mathrm{ha}^{-1}\right)$. The recommended dose of nutrients for maize as 135: 62.5: $50 \mathrm{~kg} \mathrm{~N}$, $\mathrm{P}_{2} \mathrm{O}_{5}$ and $\mathrm{K}_{2} \mathrm{O}$ hectare ${ }^{-1}$. The treatment combinations comprises two levels of recommended dose of fertilizer and two levels of biochar and biofertiliser in 15 treatments viz., $\mathrm{T}_{1}$ - (control), $\mathrm{T}_{2}-\left(5 \mathrm{t} \mathrm{ha}^{-1}\right.$ biochar $), \mathrm{T}_{3^{-}}$ (7.5 $\mathrm{t} \mathrm{ha}^{-1}$ biochar), $\mathrm{T}_{4^{-}}(75 \% \mathrm{RDF}), \mathrm{T}_{5^{-}}(100$ $\% \mathrm{RDF}), \mathrm{T}_{6^{-}}\left(75 \% \mathrm{RDF}+\right.$ biofertiliser), $\mathrm{T}_{7^{-}}$ (100\% RDF + biofertiliser), $\mathrm{T}_{8}-\left(5 \mathrm{t} \mathrm{ha}^{-1}\right.$ biochar $+75 \%$ RDF $), \mathrm{T}_{9}-\left(5 \mathrm{t} \mathrm{ha}^{-1}\right.$ biochar + $100 \% \mathrm{RDF}), \mathrm{T}_{10}-\left(7.5 \mathrm{t} \mathrm{ha}^{-1}\right.$ biochar $+75 \%$ RDF), $\mathrm{T}_{11}-\left(7.5 \mathrm{t}\right.$ ha ${ }^{-1}$ biochar $\left.+100 \% \mathrm{RDF}\right)$, $\mathrm{T}_{12}-\left(5 \mathrm{t} \mathrm{ha}^{-1}\right.$ biochar $+75 \% \mathrm{RDF}+$ biofertiliser), $\mathrm{T}_{13}-\left(5 \mathrm{t} \mathrm{ha}^{-1}\right.$ biochar $+100 \%$ $\mathrm{RDF}+$ biofertiliser $), \mathrm{T}_{14}-\left(7.5 \mathrm{t} \mathrm{ha}^{-1}\right.$ biochar + $75 \%$ RDF+ biofertiliser $), \mathrm{T}_{15}-(7.5 \mathrm{t}$ ha ${ }^{1}$ biochar $+100 \%$ RDF + biofertiliser) with two replications were statistically analyzed with randomized block design.

\section{Results and Discussion}

\section{Properties of Prosopis biochar}

Prosopis is widely grown in many parts of Tamil Nadu and it is available in large quantities particularly in dry tracts and wastelands. The data obtained from the Prosopis biochar was presented in the Table 2. The Prosopis biochar had a very little moisture $(1.52 \%)$ and $1.4 \mathrm{w} \mathrm{w}^{-1}$ of ash.

Mobile and resident matter of the biochar was $38 \mathrm{~g} \mathrm{~kg}^{-1}$ and $31 \mathrm{~g} \mathrm{~kg}^{-1}$ respectively. In respect of $\mathrm{pH}$ and EC was obtained at 8.1 and 1.45 $\mathrm{dSm}^{-1}$ of Prosopis biochar. The organic carbon content and cation exchange capacity of the biochar was $720 \mathrm{~g} \mathrm{~kg}^{-1}$ and $17.2 \mathrm{c} \mathrm{mol}$ (p+) $\mathrm{kg}^{-1}$. With respect to total nutrient content, Prosopis biochar had high amount of carbon and low amount of total nitrogen (1.82 $\left.\mathrm{g} \mathrm{kg}^{-1}\right)$. It had low amount of total phosphorus $\left(2.02 \mathrm{~g} \mathrm{~kg}^{-1}\right)$ and total potassium $\left(25.3 \mathrm{gkg}^{-1}\right)$ and also contained the exchangeable cations like calcium $\left(12.2 \mathrm{~g} \mathrm{~kg}^{-1}\right)$ and magnesium $\left(0.47 \mathrm{~g} \mathrm{~kg}^{-1}\right)$. 
Effect of biochar with fertiliser on growth, yield parameters and yield of maize in alfisols

\section{Growth parameters}

Combination of biochar and recommended dose of fertilisers had significantly increased the plant height from vegetative to harvest stage. The plant height ranged from 83 to 136 $\mathrm{cm}$ and 177 to $245 \mathrm{~cm}$ at vegetative and harvest stages respectively. Among the treatment $\mathrm{T}_{13}$ (biochar @ $5 \mathrm{t} \mathrm{ha}^{-1}+100 \%$ recommended dose of $\mathrm{N}, \mathrm{P}_{2} \mathrm{O}_{5}$ and $\mathrm{K}_{2} \mathrm{O}+$ biofertiliser) was significantly superior in improving the plant height by recording 136 $\mathrm{cm}$ and $245 \mathrm{~cm}$ followed by $\mathrm{T}_{12}$ (biochar @ 5 $\mathrm{t} \mathrm{ha}^{-1}+75 \%$ recommended dose of $\mathrm{N}, \mathrm{P}_{2} \mathrm{O}_{5}$ and $\mathrm{K}_{2} \mathrm{O}+$ biofertiliser) registered 126 and $237 \mathrm{~cm}$ at vegetative and harvest stages respectively. This might be attributed due to application of biochar could retain soil moisture and nutrients because of their porous xylem structure. These would adsorb the cation and exchange the nutrients because of their net negative charges of biochar and clay component. This was augmented with the findings of Peng et al., (2011) who revealed the increase in growth and biomass by biochar was recorded in maize with rice straw derived biochar amendment could be attributed with dry matter production.

\section{Yield components of maize}

Significant influence of biochar with fertilizers on the yield components of maize viz., hundred grain weight, cob length, cob weight was presented (Table 3). The hundred grain weight, cob length and cob weight were ranged from 17.2 to $38.9 \mathrm{~g}, 15.0$ to $23.5 \mathrm{~cm}$ and 155 to $310 \mathrm{~g}$ respectively. Among treatments, application of biochar @ $5 \mathrm{t} \mathrm{ha}^{-1}$ plus 100 per cent recommended dose of $\mathrm{N}$, $\mathrm{P}_{2} \mathrm{O}_{5}$ and $\mathrm{K}_{2} \mathrm{O}$ plus biofertiliser $\left(\mathrm{T}_{13}\right)$ recorded the highest hundred grain weight (38.9 g), cob length $(23.5 \mathrm{~cm})$ and cob weight (310 g) over other treatments and control. While comparing other treatment combinations, it was observed that the treatment received biochar @ 5 t ha ${ }^{-1}$ plus 75 per cent recommended dose of $\mathrm{N}, \mathrm{P}_{2} \mathrm{O}_{5}$ and $\mathrm{K}_{2} \mathrm{O}$ biofertiliser $\left(\mathrm{T}_{12}\right)$ recorded next best levels of hundred grain weight, cob length and cob weight of $35.0 \mathrm{~g}, 23.0 \mathrm{~cm}$ and $306 \mathrm{~g}$ respectively. The lowest hundred grain weight, cob length and cob weight of $17.2 \mathrm{~g}$, $15.0 \mathrm{~cm}$ and $155 \mathrm{~g}$ was recorded in $\mathrm{T}_{1}$ (control). This was ascribed due to application of fertiliser and biochar would increase the availability of assimilates (source) and storage (sink) exert an important regulative function on the complex process of yield formation. The present findings is accordance with Chan et al., (2008) also recorded that the lowest application of biochar@ $10 \mathrm{t} \mathrm{ha}^{-1}$ increases 42 per cent yield compared with the unamended control in radish.

\section{Grain and stover yield of maize}

Application of biochar with NPK fertilisation significantly increased the grain and stover yield (Table 4) of maize which ranged from 2,538 to $8,100 \mathrm{~kg} \mathrm{ha}^{-1}$ and 4,061 to $12,150 \mathrm{~kg}$ $\mathrm{ha}^{-1}$ respectively. While comparing the biochar treatments, it was evident that application of biochar to maize crop was significantly higher with combination of different levels of fertilisers and biofertiliser. In the treatment combinations, the treatment received biochar@ $@ 5 \mathrm{t} \mathrm{ha}^{-1}$ plus 75 per cent recommended dose of $\mathrm{N}, \mathrm{P}_{2} \mathrm{O}_{5}$ and $\mathrm{K}_{2} \mathrm{O}$ plus biofertiliser $\left(\mathrm{T}_{13}\right)$ recorded the highest grain and stover yield of 8100 and $12150 \mathrm{~kg} \mathrm{ha}^{-1}$ respectively and followed by $\mathrm{T}_{12}$ (biochar @ 5 $\mathrm{t} \mathrm{ha}^{-1}+75 \%$ recommended dose of $\mathrm{N}, \mathrm{P}_{2} \mathrm{O}_{5}$ and $\mathrm{K}_{2} \mathrm{O}+$ Biofertiliser) recorded higher grain $\left(7700 \mathrm{~kg} \mathrm{ha}^{-1}\right)$ and stover yield $(11,550 \mathrm{~kg}$ $\left.\mathrm{ha}^{-1}\right)$. The control $\left(\mathrm{T}_{1}\right)$ recorded the lowest grain and stover yield of 2538 and $4061 \mathrm{~kg}$ $\mathrm{ha}^{-1}$ respectively. 
Table.1 Physico - chemical properties of the soil

\begin{tabular}{|c|c|c|}
\hline Sl. No. & Soil Parameters & Experimental Result \\
\hline A. & Particle size distribution & \\
\hline 1. & Coarse sand (\%) & 21.2 \\
\hline 2. & Fine sand $(\%)$ & 12.4 \\
\hline 3. & Silt $(\%)$ & 32.1 \\
\hline 4. & Clay $(\%)$ & 33.8 \\
\hline 5. & Textural class & Sandy clay loam \\
\hline B. & Physical properties & \\
\hline 1. & Bulk density $\left(\mathrm{Mg} \mathrm{m}^{-3}\right)$ & 1.30 \\
\hline 2. & Particle density $\left(\mathrm{Mg} \mathrm{m}^{-3}\right)$ & 2.34 \\
\hline 3. & Water holding capacity (\%) & 41.4 \\
\hline 4. & Pore space $(\%)$ & 36.4 \\
\hline C. & Physico- chemical properties & \\
\hline 1. & Soil reaction $(\mathrm{pH})$ & 7.70 \\
\hline 2. & $\mathrm{EC}\left(\mathrm{dSm}^{-1}\right)$ & 0.43 \\
\hline 3. & $\operatorname{CEC}\left(\mathrm{c} \mathrm{mol}\left(\mathrm{p}^{+}\right) \mathrm{kg}^{-1}\right)$ & 12.3 \\
\hline D. & Chemical properties & \\
\hline 1. & Organic carbon $\left(\mathrm{g} \mathrm{kg}^{-1}\right)$ & 5.43 \\
\hline 2. & Total nitrogen $(\%)$ & 0.052 \\
\hline 3. & Total phosphorus (\%) & 0.017 \\
\hline 4. & Total potassium $(\%)$ & 0.283 \\
\hline 5. & Alk $-\mathrm{KMnO}_{4}-\mathrm{N}\left(\mathrm{kg} \mathrm{ha}^{-1}\right)$ & 232 \\
\hline 6. & Olsen $-\mathrm{P}\left(\mathrm{kg} \mathrm{ha}^{-1}\right)$ & 24.8 \\
\hline 7. & $\mathrm{NH}_{4} \mathrm{Oac}-\mathrm{K}\left(\mathrm{kg} \mathrm{ha}^{-1}\right)$ & 214 \\
\hline 8. & Exchangeable $\mathrm{Ca}\left(\mathrm{c} \mathrm{mol}(\mathrm{p}+) \mathrm{kg}^{-1}\right)$ & 3.80 \\
\hline 9. & Exchangeable $\mathrm{Mg}\left(\mathrm{c} \mathrm{mol}(\mathrm{p}+) \mathrm{kg}^{-1}\right)$ & 1.83 \\
\hline 10. & DTPA extractable $\mathrm{Zn}\left(\mathrm{mg} \mathrm{kg}^{-1}\right)$ & 0.39 \\
\hline 11. & DTPA extractable Fe $\left(\mathrm{mg} \mathrm{kg}^{-1}\right)$ & 2.99 \\
\hline 12. & DTPA extractable $\mathrm{Cu}\left(\mathrm{mg} \mathrm{kg}^{-1}\right)$ & 1.61 \\
\hline 13. & DTPA extractable $\mathrm{Mn}\left(\mathrm{mg} \mathrm{kg}^{-1}\right)$ & 0.89 \\
\hline
\end{tabular}

Table.2 General characteristics of Prosopis juliflora L. Biochar

\begin{tabular}{|l|l|l|}
\hline Sl. No. & Characters & Prosopis Wood Biochar \\
\hline 1. & Moisture $\%$ & 1.52 \\
\hline 2. & Ash w w & 1.40 \\
\hline 3. & Mobile matter $\mathrm{g} \mathrm{kg}^{-1}$ & 38.0 \\
\hline 4. & Resident matter g kg-1 & 31.0 \\
\hline 5. & $\mathrm{pH}(1: 10$ solid water suspension $)$ & 8.10 \\
\hline 6. & $\mathrm{EC}\left(\mathrm{dSm}^{-1}\right)(1: 10$ soil water extract $)$ & 1.45 \\
\hline 7. & Cation exchange capacity $\left(\mathrm{c} \mathrm{mol}\left(\mathrm{p}^{+}\right) \mathrm{kg}^{-1}\right)$ & 17.2 \\
\hline 8. & Organic carbon $\left(\mathrm{g} \mathrm{kg}^{-1}\right)$ & 720 \\
\hline 9. & Total Nitrogen $\mathrm{g} \mathrm{kg}^{-1}$ & 1.82 \\
\hline 10. & C:N ratio & 395 \\
\hline 11. & Total Phosphorus $\left(\mathrm{g} \mathrm{kg}^{-1}\right)$ & 2.02 \\
\hline 12. & Total Potassium $\left(\mathrm{g} \mathrm{kg}^{-1}\right)$ & 25.3 \\
\hline 13. & Calcium $(\mathrm{g} \mathrm{kg})^{-1}$ & 12.2 \\
\hline 14. & Magnesium $\left(\mathrm{g} \mathrm{kg}^{-1}\right)$ & 0.47 \\
\hline
\end{tabular}


Table.3 Effect of biochar with fertiliser on growth, yield parameters and yield of maize in Typic Haplustalf

\begin{tabular}{|c|c|c|c|c|c|}
\hline \multirow{3}{*}{ Treatments } & \multicolumn{5}{|c|}{ Parameters } \\
\hline & \multicolumn{2}{|c|}{ Plant Height (cm) } & \multirow{2}{*}{$\begin{array}{l}\text { Hundred } \\
\text { grain } \\
\text { weight (g) }\end{array}$} & \multirow{2}{*}{$\begin{array}{c}\text { Cob } \\
\text { length } \\
(\mathrm{cm})\end{array}$} & \multirow{2}{*}{$\begin{array}{c}\text { Cob } \\
\text { weight } \\
\text { (g) }\end{array}$} \\
\hline & Vegetative & Harvest & & & \\
\hline Absolute control & 83 & 177 & 17.2 & 15.0 & 155 \\
\hline $5 \mathrm{t} \mathrm{ha}{ }^{-1}$ Biochar alone & 93 & 188 & 24.8 & 16.9 & 173 \\
\hline $7.5 \mathrm{t} \mathrm{ha}^{-1}$ Biochar alone & 83 & 184 & 22.8 & 16.4 & 164 \\
\hline $75 \%$ RDF & 97 & 193 & 24.9 & 17.2 & 172 \\
\hline $100 \% \mathrm{RDF}$ & 108 & 220 & 28.8 & 18.4 & 210 \\
\hline $75 \%$ RDF + Biofertiliser (Azophos @ 10 packets ha ${ }^{-1}$ ) & 97 & 211 & 27.1 & 17.8 & 208 \\
\hline $100 \%$ RDF + Biofertiliser (Azophos @ 10 packets ha ${ }^{-1}$ ) & 109 & 221 & 32.0 & 18.7 & 216 \\
\hline $5 \mathrm{t} \mathrm{ha}^{-1}$ Biochar $+75 \%$ RDF & 123 & 232 & 34.8 & 22.0 & 280 \\
\hline $5 \mathrm{t} \mathrm{ha}^{-1}$ Biochar $+100 \% \mathrm{RDF}$ & 125 & 234 & 34.9 & 22.4 & 304 \\
\hline $7.5 \mathrm{t} \mathrm{ha}^{-1}$ Biochar+ $75 \% \mathrm{RDF}$ & 122 & 229 & 34.1 & 20.5 & 266 \\
\hline $7.5 \mathrm{t} \mathrm{ha}^{-1}$ Biochar $+100 \% \mathrm{RDF}$ & 116 & 227 & 34.2 & 20.1 & 246 \\
\hline $5 \mathrm{t} \mathrm{ha}^{-1}$ Biochar + $75 \%$ RDF + Biofertiliser (Azophos @ 10 packets ha $^{-1}$ ) & 126 & 237 & 35.0 & 23.0 & 306 \\
\hline 5 t ha $^{-1}$ Biochar + $100 \%$ RDF + Biofertiliser (Azophos @ 10 packets ha $^{-1}$ ) & 136 & 245 & 38.9 & 23.5 & 310 \\
\hline 7.5 t ha $^{-1}$ Biochar $+75 \%$ RDF + Biofertiliser (Azophos @ 10 packets ha $^{-1}$ ) & 113 & 222 & 33.9 & 19.2 & 229 \\
\hline $7.5 \mathrm{t} \mathrm{ha}^{-1}$ Biochar + $100 \%$ RDF + Biofertiliser (Azophos @ 10 packets ha $^{-1}$ ) & 123 & 229 & 34.6 & 21.6 & 276 \\
\hline Mean & 110 & 217 & 30.5 & 19.5 & 234 \\
\hline SEd & 2.09 & 2.95 & 2.1 & 2.3 & 4.8 \\
\hline $\mathrm{CD}(\mathrm{p}=0.05)$ & 4.50 & 5.77 & 4.5 & 4.1 & 6.1 \\
\hline
\end{tabular}


Table.4 Effect of biochar with fertilisers in grain, straw yield $\left(\mathrm{kg} \mathrm{ha}^{-1}\right)$ and crude protein (\%) of maize in Typic Haplustalf

\begin{tabular}{|c|c|c|c|}
\hline Treatment & $\begin{array}{l}\text { Grain yield } \\
\quad\left(\mathrm{kg} \mathrm{ha}^{-1}\right)\end{array}$ & $\begin{array}{l}\text { Stover yield } \\
\quad\left(\mathrm{kg} \mathrm{ha}^{-1}\right)\end{array}$ & $\begin{array}{c}\text { Crude } \\
\text { Protein }(\%)\end{array}$ \\
\hline Absolute control & 2538 & 4061 & 5.0 \\
\hline $5 \mathrm{tha}^{-1}$ Biochar alone & 4600 & 7360 & 5.6 \\
\hline $7.5 \mathrm{t} \mathrm{ha}^{-1}$ Biochar alone & 4850 & 7760 & 5.2 \\
\hline $75 \% \mathrm{RDF}$ & 4850 & 6790 & 5.6 \\
\hline $100 \% \mathrm{RDF}$ & 5075 & 7105 & 6.4 \\
\hline $75 \%$ RDF + Biofertiliser (Azophos @ 10 packets ha $^{-1}$ ) & 5000 & 7000 & 5.9 \\
\hline $100 \%$ RDF + Biofertiliser (Azophos @ 10 packets ha ${ }^{-1}$ ) & 5125 & 7175 & 6.2 \\
\hline $5 \mathrm{tha}^{-1}$ Biochar $+75 \% \mathrm{RDF}$ & 7150 & 10725 & 8.3 \\
\hline $5 \mathrm{t} \mathrm{ha}^{-1}$ Biochar $+100 \% \mathrm{RDF}$ & 7275 & 10913 & 8.5 \\
\hline $7.5 \mathrm{t} \mathrm{ha}^{-1}$ Biochar+ $75 \% \mathrm{RDF}$ & 7450 & 11175 & 7.4 \\
\hline $7.5 \mathrm{t} \mathrm{ha}^{-1}$ Biochar $+100 \% \mathrm{RDF}$ & 7625 & 11438 & 6.9 \\
\hline 5 tha $^{-1}$ Biochar + $75 \%$ RDF + Biofertiliser (Azophos@10 packets ha ${ }^{-1}$ ) & 7700 & 11550 & 9.3 \\
\hline $5 \mathrm{t} \mathrm{ha}^{-1}$ Biochar + $100 \% \mathrm{RDF}+$ Biofertiliser (Azophos @ 10 packets ha $^{-1}$ ) & 8100 & 12150 & 9.9 \\
\hline 7.5 t ha $^{-1}$ Biochar $+75 \%$ RDF + Biofertiliser (Azophos @ 10 packets ha $^{-1}$ ) & 7600 & 11400 & 6.6 \\
\hline $7.5 \mathrm{tha}^{-1}$ Biochar $+100 \% \mathrm{RDF}+$ Biofertiliser (Azophos @10 packets ha $\left.{ }^{-1}\right)$ & 7725 & 11588 & 7.7 \\
\hline Mean & 6178 & 9213 & 7.0 \\
\hline SEd & 26 & 35 & 0.15 \\
\hline $\mathrm{CD}(\mathrm{p}=0.05)$ & 55 & 65 & 0.31 \\
\hline
\end{tabular}


Fig.1 Structure of Prosopis biochar by using scanning electron microscope

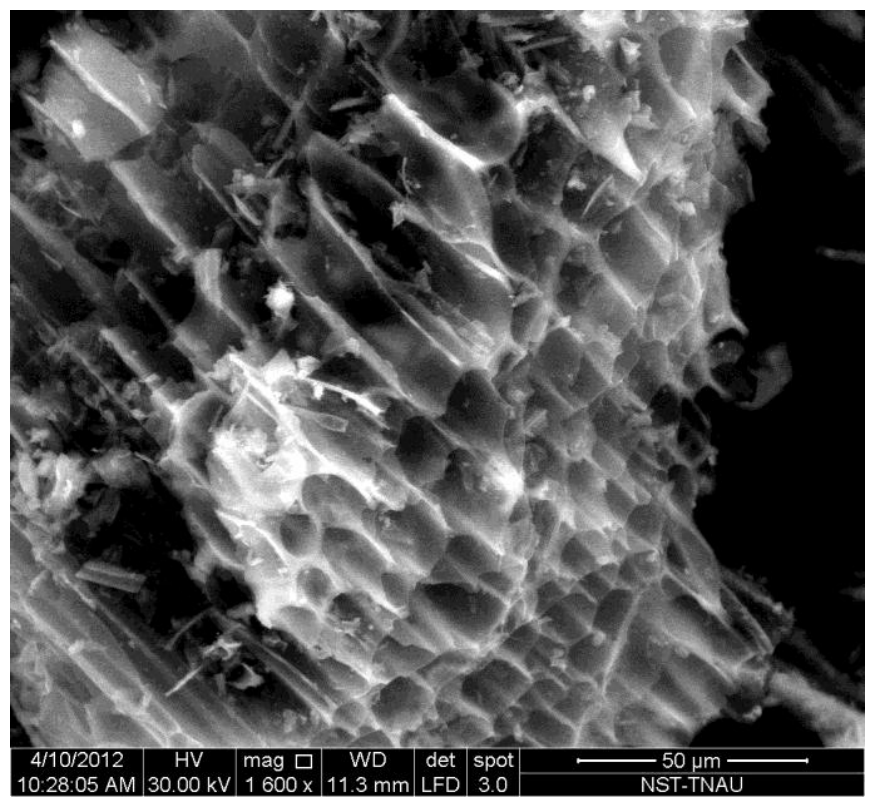

This may be attributed that application of biochar with $\mathrm{N}$ would increase nitrogen availability its regulating nitrate reductase by high negative charged biochar particles increased the grain and stover yield of maize. And also the pattern of nutrient release to the environment was slower when compared to control. This was in agreement with the findings of Baronti et al., (2010) reported that application of biochar @ $10 \mathrm{t} \mathrm{ha}^{-1}$ recorded higher grain production in maize, wheat and also in ryegrass.

\section{Quality}

\section{Crude protein content}

The crude protein content of maize varied from 5.0 to 9.9 per cent showing the significant influence of biochar and fertilisers (Table 4). Among the treatments, biochar @ 5 $\mathrm{t} \mathrm{ha}^{-1}$ plus 100 per cent recommended dose of $\mathrm{N}, \mathrm{P}_{2} \mathrm{O}_{5}$ and $\mathrm{K}_{2} \mathrm{O}$ plus biofertilisers $\left(\mathrm{T}_{13}\right)$ recorded significantly the highest crude protein content $(9.9 \%)$ in maize followed by biochar @ $5 \mathrm{t} \mathrm{ha}^{-1}$ plus 75 per cent recommended dose of $\mathrm{N}, \mathrm{P}_{2} \mathrm{O}_{5}$ and $\mathrm{K}_{2} \mathrm{O}+$ biofertiliser $\left(T_{12}\right)$ recorded higher $(9.3 \%)$ crude protein content in maize as compared over to other treatments and control. This might be due to increase the available of nitrogen and its uptake and storage in grain. Potassium uptake by maize has also marked due to biochar with fertiliser application. Rondon et al., (2007) who reported that different types of biochar applied in soil influencing high $\mathrm{K}$ uptake by maize. Usherwood (1985) who reported that potassium can play a role in quality development of maize, when supplement $\mathrm{K}$ fertilisation was applied to maize, it produced on increase in grain protein content and amino acid content and Yang et al., (2004) also supporting this high protein concept.

It could be concluded that application of biochar along with fertiliser and biofertiliser would increase the maize growth and yield. This may be due biochar had porous medium and the graphite sheet could be adsorbed higher moisture and nutrient. The oxidation of functional groups of biochar would adsorb more cation and exchange with root hairs $\left(\mathrm{H}^{+}\right)$ leads to higher nutrient assimilation by plants. 
Also biochar leads to increase the organic carbon in soil by way of less oxidation of organic matter in to $\mathrm{CO}_{2}$ leads to sequester carbon in soil. These can applicable when soils are contaminated with heavy metals, biochar could act like an organic matter by adsorb the heavy metal through ligand exchange mechanism to less availability of heavy metal into ground water and phyto toxicity. Less $\mathrm{CO}_{2}$ emissions also leads to reduce the climate change effect on environment.

\section{Acknowledgements}

The authors are grateful to SCAD Engineering College at Cheranmahadevi, Tirunelveli, Tamil Nadu where the materials (Prosopis Biochar) procured for this study.

\section{References}

Amonette, J.E., and Joseph, S. 2009. Characteristics of biochar: microchemical properties. In: J. Lehmann, J and Joseph, S, (Eds.) Biochar for environmental management - science and technology. Earthscan, London, pp.33-52.

Baronti, S., G. Alberti, G. Vedovedelle, F. Gennaro di, G. Fellet, L. Genesio, F. Miglietta, A. Peressotti and Vaccari. F.P. 2010. The biochar option to improve plant yields: first results from some field and pot experiments in Italy, Italian Journal of Agronomy. 5 (1): 3-12 (2010).

Blackwell, P., G. Riethmuller and Collins, M. 2009. Biochar application to soil. In: Lehmann, J. and Joseph, S (Eds) Biochar for environmental management: science and technology. Earthscan, London. pp. 207-226.

Chan, K.Y., L. Van Zwieten, I. Meszaros, A. Downie and Joseph. S. 2008. Using poultry litter biochars as soil amendments. Aust J Soil Res. 46:437 444.

Cheng, C.H., J. Lehmann, J.E. Thies and S.D. Burton. 2008. Stability of black carbon in soils across a climatic gradient. J Geophys Res. pp.113.

Downie, A., A. Crosky and Munroe, P., 2009. Physical properties of biochar. In: Biochar for Environmental Management: Science and Technology, Earthscan, London. pp. 13-32.

Glaser, B., J. Lehmann and Zech, J.2002. Ameliorating physical and chemical properties of highly weathered soils in the tropics with charcoal $-\mathrm{A}$ review. Biol. and Fert. of Soil., 35: 219-230.

Hugh McLaughlin. 2010. Biochar Revolution: Transforming Agriculture \& Environment. pp. 82-91.

Laird, D., P. Fleming, B.Q. Wang, R. Horton and Karlen, D. 2010. Biochar impact on nutrient leaching from a Midwestern agricultural soil. Geoderma. 158: 436-442.

Liang, B., J. Lehmann, D. Solomon, J. Kinyangi, J. Grossman, B. O'Neill, J.O. Skjemstad, J. Thies, F.J. Luizao, J. Petersen and Neves, E.G. 2006. Black carbon increases cation exchange capacity in soils. Soil Sci Soc Am J. 70:1719-1730.

Major, J., J. Lehmann, M. Rondon and C.Goodale. 2010. Fate of soil-applied black carbon: downward migration, leaching and soil respiration. Global Change. Biol. 16:1366-1379.

Merrill, A.L., and Watt, B.K. 1973. Energy value of foods, basis and derivation. United States Department of Agriculture Handbook 74. USDA, Washington, Dc.

Peng, X., L.L. Ye, C.H. Wang, H. Zhou and Sun, B. 2011. Temperature- and duration- dependent rice strawderived Biochar: Characteristic and 
it's effects on soil properties of an Ultisol in southern China. Tillage Research. 112:159-166.

Rondon, M., J. Lehmann, J. Ramírez, and Hurtado, M. 2007. Biological nitrogen fixation by common beans (Phaseolus vulgaris L.) increases with bio-char additions. BiolFertil Soils., 43:699 708.
Usherwood, N.R. 1985. The role of potassium in crop quality. Potassium in Agriculture. ASA.CSSA and SSSA, Madison, WI. pp. 489-513.

Yang. S., L. Fengmin, S.S. Malhi, P. Wang, O. Suo and Wang. J.2004. Long- term fertilization efforts on crop yield and nitrate nitrogen accumulation in soil in north-western china.

\section{How to cite this article:}

Gokila, B. 2017. Climate Change Impact on Yield, Quality and Soil Fertility of Maize in Sandy Clay Loam as Influenced by Biochar and Inorganic Nutrients in Typic Haplustalf. Int.J.Curr.Microbiol.App.Sci. 6(11): 3150-3159. doi: https://doi.org/10.20546/ijcmas.2017.611.369 